\title{
6. Caring, rescuing or punishing? Rewriting $R M S v$ Spain (ECtHR) from an integrated approach to the rights of women and children in poverty
}

\section{Valeska David*}

\section{INTRODUCTION}

$R M S v$ Spain concerns the removal of the applicant's daughter and her placement in institutional and foster care with a view to her adoption, on the sole account of her mother's poverty. ${ }^{1}$ In a 2013 judgment, the European Court of Human Rights (hereinafter, ECHR or 'the Court') found for the applicant and declared a violation of her right to family life, while dismissing her complaint on discrimination. At first glance, the case may not seem the most appealing one from the European Court's docket to reflect upon and rewrite. The judgment has not attracted much scholarly attention, ${ }^{2}$ and in any case, the ruling is certainly welcome. It conveys the message that financial hardship alone cannot justify the separation of children from their families. It also underscores the role of the state in supporting families to overcome material hurdles, instead of adopting the

* This research has been funded by the Interuniversity Attraction Poles Programme initiated by the Belgian Science Policy Office, more specifically the IAP 'The Global Challenge of Human Rights Integration: Towards a Users' Perspective' <www.hrintegration.be>.

1 RMS v Spain App no 28775/12 (ECHR, 8 June 2013).

2 See for example Cristina Castellote, 'R.M.S. v Spain: A mother's economic hardship does not justify permanent separation from her child' (2013) 2 CHRLR 272. Brief references to the case can also be found in Françoise Tulkens, 'The European Convention on Human Rights and the economic crisis: The issue of poverty' (2013) EUI Working Papers AEL 2013/08, 12-13, accessed 13 March 2017 at http://cadmus.eui.eu/bitstream/handle/1814/28099/AEL_2013_08. pdf? sequence $=1 \&$ isAllowed $=\mathrm{y}$. 
most drastic measure envisaged to protect children. Ultimately, the case does not posit a novel question, but rather an old one: the problem of 'rescuing' children from poor families. This issue has been widely debated in several countries where the interactions between child welfare systems, poverty and disadvantaged communities - such as Afro-American and Indigenous families - have disquieted many. ${ }^{3}$ Nonetheless, recently similar longstanding concerns have gained resonance in Europe. In 2015 the European Parliamentary Assembly drew attention to the fact that, despite the absence of statistics, evidence suggests that 'children from vulnerable groups are disproportionally represented in the care population of member states', whereas no evidence suggests that parents who are poor, less educated, belong to minorities or have a migration background are more likely to abuse or neglect their children. ${ }^{4}$ The vulnerability of disadvantaged families to forcible separation may be exacerbated by economic crises and liberalization trends which tend to add to the 'privatization' of child-care responsibilities. ${ }^{5}$

In this context, and despite first impressions, there are good reasons to choose RMS. Even though the judgment is not the only one issued by the Strasbourg Court which deals with the taking of children from impoverished families into care ${ }^{6}$ this one offers particularly interesting

3 In the United States, for instance, the debate has focused on the punitive character of foster care systems with regard to Afro-American and 'Latinos' families, particularly, poor mothers. In Australia similar discussions have taken place with regard to children from indigenous communities. See for example Dorothy E Roberts, Shattered Bonds: The Color of Child Welfare (Basic Civitas Books 2002) 7-10; Human Rights and Equal Opportunity Commission, Report of the National Inquiry into the Separation of Aboriginal and Torres Strait Islander Children from Their Families (1997); ATD Fourth World, How Poverty Separates Parents and Children: A Challenge to Human Rights (2004). Another area of concern is the disproportional removal of children from parents with disabilities. See for example Victorian Office of the Public Advocate, OPA Position Statement: The removal of children from their parent with a disability (2012), accessed 13 March 2017 at http://www.publicadvocate.vic.gov.au/our-services/publications-forms/72the-removal-of-children-from-their-parent-with-a-disability?path=.

4 Council of Europe, Parliamentary Assembly of 13 March 2015, Social services in Europe: legislation and practice of the removal of children from their families in Council of Europe member States (2015) Doc 13730, para 4.

5 Dorothy E. Roberts, 'The dialectic of privacy and punishment in the gendered regulation of parenting' (2009) 5 SJCR\&CL 191, 192-3.

6 Other judgments dealing with this matter are: Moser v Austria App no 12643/02 (ECHR, 21 September 2006); Wallová and Walla v The Czech Republic App no 23848/04 (ECHR, 26 October 2006); Havelka and Others v the Czech Republic App no 23499/06 (ECHR, 21 June 2007); Saviny v Ukraine App no 39948/06 (ECHR, 18 December 2008); A.K. and L. v Croatia App no 37956/11 
elements for analysis. To start with, $R M S$ concerns the parenting rights of an afro-descendant and impoverished single mother living within an unconventional family. ${ }^{7}$ In the second place, the case raises some structural issues underlying the dynamics between child welfare systems and families living in poverty (particularly those led by single women) such as cultural prejudice manifested in compounded stereotypes. Third, the case also poses the question of the fairness and participation afforded to extended family members and children in decision-making processes. In sum, $R M S$ allows us to examine the extent to which supranational monitoring bodies can apply human rights standards in a way that captures the experience of poor women and children experiencing both marginalization on account of intersecting identities and socio-economic disadvantages.

In what follows, I attempt to explain why these challenges can be better undertaken by adopting an integrated approach to human rights law. I start by outlining the main factual and legal dimensions of the case, which I situate not only in the Court's case law but also in the Spanish institutional context. Next, I justify my proposal of infusing the case with children's rights, gender and poverty perspectives on human rights law. By combining and incorporating these approaches, including their respective theoretical and normative frameworks, I then proceed to critically analyse the Court's reasoning in $R M S$ while acknowledging that this deserves to be commended in several respects. The chapter first problematizes the allocation of children's care and well-being to the 'private' realm of families and questions the way the ECHR assessed the impermissibility of family separation on the ground of poverty. Second, attention is drawn to the compounded stereotypes underlying the decisions of the Spanish authorities and which the ECHR failed to challenge. Third, the chapter revisits the ECHR's scrutiny of the domestic judicial control and decision-making process over both the girl's removal and her placement.

In the rewritten judgment, I attempt to recast the Court's reasoning and argumentation with regard to the right to family life and the prohibition of discrimination. Moreover, in the case of the latter I suggest that the Court should have analysed the merits of the complaint, which leads me to propose a different outcome on this part of the applicant's claim.

(ECHR, 8 January 2013); RMS v Spain (n 1); N.P. $v$ the Republic of Moldova App no 58455/13 (ECHR, 6 October 2015).

7 The subsequent case of Soares de Melo v Portugal also concerns a young single mother living in poverty. See Soares de Melo v Portugal App no 72850/14 (ECHR, 16 February 2016). 


\section{FACTUAL BACKGROUND, LEGAL ARGUMENTS AND RELEVANT CONTEXT}

\subsection{Facts and Legal Claims}

The applicant was a Spanish woman of Guinean origin who, at the time of the events, was 26 years old and living within an extended family comprised by her grandmother, great-uncle and her three children. She was an agricultural worker in Andalusia while temporally grape picking in France. Trying to avoid taking her two eldest sons with her when she had to go to France, she placed them in the foster care of her great-uncle, who looked after them when she was away. Yet, they all lived together.

On 23 August 2005 the applicant's daughter ('G.') aged three years and ten months at the time, was taken away from her mother at the request of a social worker, after the applicant had visited the social services seeking socio-economic support ('work, food and housing'). Two days later the administrative authorities issued a provisional decision declaring the girl's abandonment. The decision cited, among other factors, the applicant's serious financial hardship, the child's lack of hygiene, the fact that she was inappropriately dressed for the summer weather, her dry skin marked with scratches and her anxiety about food. ${ }^{8}$ The girl was placed in a children's home in Granada and subsequently transferred to another home more than 130 kilometres away, without her mother's knowledge and consent. The applicant was at first allowed supervised meetings with her daughter. But these were soon discontinued because of the applicant's allegedly disruptive behaviour. Mother and daughter saw each other for the last time on 27 September 2005.

In February 2006 administrative authorities confirmed the girl's abandonment and initiated proceedings for placing her in pre-adoption foster care. However, the social services had entered into contact with the foster family just few days after the mother-child separation. ${ }^{9}$ The applicant unsuccessfully opposed the declaration of abandonment, the discontinuation of her visits and the decision to place her daughter with a foster family. In May 2007 a judicial hearing was held concerning the suspension of visits and the applicants' appeal against the declaration of abandonment. The judgment - upheld on appeal - found against the applicant. Subsequent judgments issued in 2009 and 2010 approved all

8 The problems with her skin were due to an atopic seborrheic dermatitis; a fact known to the authorities.

$9 \quad R M S v \operatorname{Spain}(\mathrm{n} 1)$ paras 15, 26. 
the administrative decisions taken. The applicant's request to place G. in the foster care of her great-uncle was dismissed and he was not allowed to give his testimony in court.

It is relevant to take a closer look at the reasons invoked by the social worker who requested the removal of the girl, as well as at those provided by the administrative and judicial authorities involved. Besides the state of the girl referred to above, the motives put forward included: the applicant's perceived defiant attitude, aggressive behaviour, alleged mental illness, lack of social skills or ignorance; her insufficient efforts to avoid a situation of social and professional isolation and the incapacity of her great-uncle to look after her children. Strikingly, no expert reports were cited to support those assertions. No evidence of child abuse, lack of affection or maltreatment was ever found. Additional factors considered by the authorities were: the period of time without any mother-child contact; the fact that her other children were in the foster care of the applicant's great-uncle and her new pregnancy.

Relying on article 8 of the European Convention of Human Rights (hereinafter 'the Convention'), the applicant complained that she was unjustly separated from her daughter. She asserted that she had always worked and had both the means and aptitude to raise her daughter. In her view, the social services had been biased against her. They had put her daughter in foster care without the domestic courts having ruled on her supposed abandonment and judges had refused to examine the irregularities in the administrative proceedings. ${ }^{10}$ Under article 14 the applicant claimed that she was discriminated against in the enjoyment of family life on the grounds of her race, her Guinean origin, the colour of her skin, her physical appearance and her culture and lifestyle.

\subsection{RMS Outside and Inside the Court's Jurisprudence}

Within the Spanish context, $R M S$ is not an isolated case. ${ }^{11}$ Institutional and structural factors may contribute to that. Amongst the institutional factors, it is relevant to consider the domestic legislation governing the case (dictated by autonomous community regulations not harmonized

\footnotetext{
$10 \quad R M S v$ Spain (n 1), paras 64-65.

11 See Patricia Manrique, 'Un centenar de casos contra la retirada de tutelas sobre los menores' (Periódico Diagonal, 16/04/2013), accessed 13 March 2017 at www.diagonalperiodico.net/libertades/centenar-casos-contra-la-retirada-tutelassobre-menores.html.
} 
at the national level) $)^{12}$ and the way it operated in practice. At the time of the events, social services were legally entitled to remove children and automatically undertake their guardianship whenever they considered them to be in abandonment. Judicial review of the removal would proceed if requested by the parents when circumstances had changed..$^{13}$ In practice, realization of judicial control could take a considerable time. Meanwhile administrative authorities were entitled to provisionally place children in foster care. Where the child had spent significant time with a foster family, child return became unlikely, as $R M S$ testifies. ${ }^{14}$ This case also suggests that such institutional design may have particular detrimental effects for socio-economically disadvantaged families. In fact, persons living in poverty face countless obstacles in claiming their rights and accessing justice in both administrative and judicial settings. ${ }^{15}$

In June 2013 the ECHR found that Spain had violated the applicant's right to private and family life, while considering it unnecessary to examine her complaint on discrimination. The judgment is not isolated in the Court's jurisprudence either. In 2006 and 2007 the Court ruled similarly in cases against Austria and the Czech Republic. ${ }^{16}$ In these cases children were separated from their families on account of their parents' poverty, more specifically, because they lacked adequate housing (which in $R M S$ was not at issue). But besides differences amongst the applicants and the circumstances of the cases, there are also interesting divergences in the approach adopted by the Court. Notably, in the judgments preceding $R M S$, the Court scrutinized the care orders as serious interferences with the right to family life, and therefore, it analysed their legality, aim and proportionality. It concluded that since material hardship was not

12 Committee on the Rights of the Child, Concluding observations (2010) Spain, CRC/C/ESP/CO/3-4, para 9; The EU Parliamentary Assembly has also expressed concern about the lack of unified nationwide standards on the matter: Council of Europe, Parliamentary Assembly (n 4), para 80.

13 Civil Code, articles 172-173; Organic Act No 1/1996 of 15 January, articles 17-18, 20-22; Civil Procedure Act of 2000, articles 779-780; Autonomous Community of Andalusia Act No 1/1998 of 20 April, article 23.

14 Although domestic laws applicable at the time of $R M S$ have been amended, they have not fully overcome reported shortcomings. See for example Pilar Moreda, 'Riesgo, Desamparo y Acogimiento de Menores. Actuación de la Administración e Intereses en Juego' (2011) 15 AFDUAM 15, 52-53.

15 Magdalena Sepúlveda Carmona, 'Report of 9 August 2012 of the UN Special Rapporteur on Extreme Poverty and Human Rights, submitted in accordance with Human Rights Council resolution' (2012) 17/13. A/67/278.

16 Moser v Austria (n 6); Wallová and Walla v The Czech Republic (n 6); Havelka and Others $v$ the Czech Republic (n 6). 
sufficient to justify a family breakdown and since other less restrictive measures could have been taken, the separations were not proportional, that is, not necessary in a democratic society. ${ }^{17}$ As seen below, this unequivocal declaration is not to be found in $R M S$. It should be observed, however, that in a 2015 judgment concerning a child's placement for reasons mainly related to her mother's poverty, the Court correctly relooked at its analysis on legality, aim and proportionality. ${ }^{18}$ As such, this recent judgment has been taken into account when rewriting $R M S$.

In $R M S$ the Court centred its examination not on the legitimacy of a state interference, but on the state's positive obligations in terms of 'a parent's right to the taking of measures with a view to his or her being reunited with the child'. ${ }^{19}$ After revising the steps undertaken by the administrative authorities in $R M S$, the Court took the view that they acted with a serious lack of diligence. As to the decision-making process and given the applicant's complaint that domestic courts did not examine the irregularities in the administrative proceedings, the Court was mostly satisfied with the protection of the applicant's interests before the judicial authorities. ${ }^{20}$ The Court then proceeded to evaluate the state conduct alongside two stages in the girl-mother separation: the taking into care and the placement in pre-adoption foster care.

With respect to the taking of the girl into care, the Court was of the view that in the circumstances of the case the decision adopted by the social worker was understandable. However, it should have been swiftly followed by appropriate measures to examine the child-parent situation and reunite the family. ${ }^{21}$ Recalling that the applicant's ability to provide her daughter with educational and emotional support was not at issue, the C) urt observed that the care order 'was made because of the applicant's unficult financial situation at the time, without any account being taken of subsequent changes in her circumstances'. ${ }^{22}$ The shortage of funds faced by the applicant was a situation 'which the national authorities could have helped remedy by means other than the complete break-up of the family'. ${ }^{23}$

With regard to the girl's placement in pre-adoption foster care, the Court called into question the assessment of the administrative authorities and,

17 Wallová and Walla v The Czech Republic (n 6), paras 74-78; Havelka and Others $v$ the Czech Republic (n 6), paras 55-57, 60-63.

18 N.P. $v$ the Republic of Moldova (n 6).

$19 R M S v \operatorname{Spain}(\mathrm{n} 1)$ para 81.

20 ibid, para 78.

21 ibid, para 83.

22 ibid, para 85.

23 ibid, para85-86. 
to a lesser extent, also that of the domestic courts. ${ }^{24}$ The Court pointed out that 'the applicant was forced to prove that she was a good mother to her child and when she submitted evidence to that end the competent courts considered, without any supporting arguments, that it was insufficient to outweigh the assessment of the administrative authorities' ${ }^{25}$ It also observed that domestic courts validated the pre-adoption placement mainly because of the lack of contact between the girl and her mother during several years, which actually was the result of the administrative and judicial decisions taken. ${ }^{26}$ The Court concluded: 'the Spanish authorities failed to undertake appropriate and sufficient efforts to secure the applicant's right to live with her child, in breach of her right to respect for her private and family life'. ${ }^{27}$

As indicated at the outset, and starting from an integrated perspective of human rights norms concerning women and children living in poverty, I argue that three aspects of the Court's reasoning in $R M S$ warrant a critical appraisal. First, the Court's ambiguous argumentation regarding the impermissibility of family separation on the sole account of poverty. Second, the Court's failure to unveil and question the compounded stereotypes underlying the decisions of the Spanish authorities. Third, I contend that the Court should have further scrutinized the judicial control and the decision-making process over both the girl's removal and her placement. In the course of this critical assessment I will also highlight the aspects of the judgment that deserve to be praised. But before turning to this, the following section sketches the normative and theoretical underpinnings of the integrated approach to human rights law undertaken in this chapter.

\section{INTEGRATING THEORETICAL AND NORMATIVE PERSPECTIVES ON THE RIGHTS OF CHILDREN AND WOMEN IN POVERTY}

\subsection{Preliminary Remarks on an Integrated View of Human Rights Law}

The so-called fragmentation of human rights law tends to feed an isolated view of both rights holders and rights regimes. ${ }^{28}$ This holds true for

\footnotetext{
24 ibid, paras 87-89.

25 ibid, para 89.

26 ibid, para 92.

27 ibid, para 93.

28 Eva Brems, 'Should pluriform human rights become one? Exploring the benefits of human rights integration' (2014) 4 EJHR 447, 452.
} 
the ECHR insofar as this regional court is designed to afford general protection only to individuals who bring a complaint about violations of their (mostly civil and political) rights enshrined in the ECHR. Thus, in $R M S$ the Court focused on the applicant, the mother who lost her daughter, and her right to family life protected by the Convention. While this approach is justified, a more integrated view of human rights law is desirable. The following lines argue in favour of incorporating theoretical and normative insights from children's and women's rights as well as developments concerning the rights of people living in poverty. Why do so?

A first reason seems obvious: the rights of the applicant's daughter, a girl, were also affected. Second, the human rights experiences of mother and child were compounded by disadvantages related to both gender and poverty. Integrating these perspectives facilitates a more comprehensive and context-sensitive examination of the case. Not only are all rights holders and normative frameworks involved considered, but artificial boundaries between civil/political and social/economic rights are also eroded. Thus, this chapter builds upon two dimensions of integration that help in doing better justice to the lived experience of the applicant and her daughter, namely, intersectionality and indivisibility. As will become clear in the following sections, the violations of their rights occur at the intersection of their identities and socio-economic disadvantage. Unjust family separation and forced child removal are human rights violations that particularly affect single women and children living in poverty. Additionally, the integrated perspective defended here facilitates an understanding of the right to family life that incorporates aspects of socio-economic protection without which the former would be of little relevance in a case like $R M S$.

\subsection{An Integrated Approach to Caring}

Care is an essential aspect of human existence. Our lives are interdependent with the lives of others in multiple ways that engage our experiences as both caregivers and care-receivers. ${ }^{29} \mathrm{~A}$ case like $R M S$ reminds us that care is a need for both parents and children. From a human rights perspective, this translates into the right of the former to care for their children and the right of the latter to be cared for by their parents. Such a right of parents and children is covered, inter alia, by the right to family life derived from

29 Robin L West, Re-Imagining Justice: Progressive Interpretations of Formal Equality, Rights, and the Rule of Law (Ashgate 2003) 94-5. 
the right to private life, as acknowledged by the ECHR. ${ }^{30}$ In addition, the right of a child to be cared for by his or her parents has explicit recognition in article 7 of the Convention on the Rights of the Child (hereinafter, $\mathrm{CRC}$ ). These rights are not only vested in parents and children sensu stricto; they extend well beyond the context of nuclear families to encompass the reality of diverse families. ${ }^{31}$ Moreover, the dynamics of care are not static or unidirectional and, of course, care is neither just a (private) matter for families.

Society's functioning is premised upon chains of mutual dependence and care. In one way or another all institutions are sustained by the (uncompensated and undervalued) care work undertaken within families and primarily by women. This fact reinforces the claim that states must take part in caregiving by providing support and protecting both caregivers and care-receivers against subordination and impoverishment. Normative recognition of the societal value of and state responsibility in caregiving relations, however, still falls short of what it ought to be. ${ }^{32}$ Yet, some recognition can be found in a number of provisions of the CRC. Having stated the primary responsibility of parents in child-rearing, articles 18(2), 19(2), 24(2)(e)(f) and 27(1) and (3) demand that the state should render appropriate assistance to caregivers, to ensure the development of institutions, facilities and services for the care of children; to provide parents and other caregivers with social programs and material support to ensure children an adequate standard of living. Importantly, state support and involvement in child upbringing is not only in the interest of parents/care-givers, it is also in the interest of children. This triangular relation (state-caregivers-children) referred to as the trias pedagogica is characteristic of the children's human rights framework. ${ }^{33}$

When the above societal dimension is forgotten and caregiving,

30 Ursula Kilkelly, 'Effective protection of children's rights in family cases: An international approach' (2002) 12 TL\&CP 335, 353; European Union Agency for Fundamental Rights and Council of Europe, Handbook on European Law Relating to the Rights of the Child (2015) 76-86.

31 Committee on the Rights of the Child, General comment No 14 on the Right of the Child to have his or her best interests taken as a primary consideration (article 3, para. 1) (2013) $\mathrm{CRC} / \mathrm{C} / \mathrm{GC} / 14$, para 65.

32 So far neither the right to work nor the right to family life or to protection of the family seem to encompass care work. Moreover, in the social and cultural imaginary caregiving is generally devalued. On possibilities to subvert the social meaning of caregiving see Laura T Kessler, 'The politics of care' (2008) 23 WJLG\&S 169, 169-ff.

33 Jan C M Willems, 'The children's Law of Nations: The international rights of the child in the Trias Pedagogica' in Jan C M Willems, Developmental and 
particularly child-rearing responsibilities, are located in the exclusive and 'private' confines of families or markets - when families can afford resorting to the latter - any 'failure' in child-rearing may be attributed to punishable individual faults which children must be rescued from. Material or environmental deficits are often viewed through this prism. The long history of difficult encounters between socio-economically disadvantaged families and foster care systems is closely related to the idea that poverty coincides with faulty parenthood and that satisfaction of children's needs requires taking them away. ${ }^{34}$

\subsection{Child-protection, Mother-punishment Dynamics and Compounded Stereotypes}

Although the concerns arising from the conflation of poverty with neglect are often expressed in terms of the harm inflicted upon parents and children living in poverty, this account needs to be gendered since women are overwhelmingly responsible for child upbringing. Martha A Fineman coined the concept of 'the neutered mother' to criticize the way the institution of 'Mother' has been detached from context. The mother, she argues, is conceptually separated from her children; she is de-classed and de-raced..$^{35}$ As explained by Fineman, this process of de-contextualization has gone hand in hand with upholding the ideal of family premised on the couple-based family unit: the traditional nuclear family. ${ }^{36}$ Not only does the heteronormative family get thereby normalized, but so do culturally dominant narratives such as those of the white, Christian, middle-class family. ${ }^{37}$ Accordingly, single mothers and children who experience poverty and live within an extended family, as in the $R M S$ case, embody a deviant family. Moreover, their poverty adds to the risk of having their family ties undervalued and severed..$^{38}$ Inasmuch as child-care work is undervalued,

Autonomy Rights of Children. Empowering Children, Caregivers and Communities (Intersentia 2007) 84.

34 Dorothy E Roberts, 'Child Welfare and Civil Rights' (2003) UILR 171,

175; Tanya A Cooper, 'Racial Bias in American Foster Care: The National Debate' (2013) 97 MLR 215, 227 (citing Leroy H Pelton, 1989 at xiii-xiv).

35 Martha A Fineman, The Neutered Mother, the Sexual Family and Other Twentieth Century Tragedies (Routledge 1995) 67.

36 ibid, 88-89.

37 Janet L Wallace and Lisa R Pruitt, 'Judging parents' (2012) 1 MLR 95, 116; Annette R Appell, 'Protecting children or punishing mothers: Gender, race and class in the child protection system' (1997) 48 SCLR 577, 585.

38 Some suggest that among the factors of deviance, it is poverty that primarily subjects families to the suspension of their rights to privacy and protection against 
women are also more exposed to economic deprivation. This is made visible when they have no choice but to turn to the state for support, as the applicant in $R M S$ did. Where the state's answer to that consists of child-mother separation, such response risks being more punitive of the mother's 'failure' than protective of the child. This is quite problematic from the perspective of children's rights too, insofar as the child's interests and needs then tend to be replaced by others' social standards. ${ }^{39}$

As discussed below, the $R M S$ case attests that underlying the process of 'othering' single poor mothers may be stereotypes and bias concerning both gender roles (particularly in regard to motherhood) ${ }^{40}$ and the experience of poverty. Stereotypes, as defined by Rebecca Cook and Simone Cusak, are generalized views or preconceptions about the attributes of members of a particular group or about the roles they should perform in society. ${ }^{41}$ Like these authors, the Committee on the Elimination of Discrimination against Women (CEDAW Committee) has paid particular attention to harmful gender stereotypes and has made a human rights obligation of their dismantling. ${ }^{42}$ Typical gender stereotypes of women portray them as being the home and child carer. These kinds of harmful categorizations fall under the scope of discrimination against women. ${ }^{43}$ In recent years UN Human Rights mechanisms have also called upon states to tackle harmful stereotypes about people living in poverty, who are often perceived as lazy, irresponsible, indifferent to their children's health and education,

state intervention. See Khiara M Bridges, 'Privacy rights and public families' (2011) 34 HJL\&G 113, 117-19, 150-3.

39 On how children's needs are often replaced by the needs of others see Abdullahi An-Na'Im, 'Cultural transformation and Normative Consensus on the Best Interest of the Child' (1994) 8 IJL\&F 62, 73-4.

40 See among others, Emily Winograd, 'Expecting the unattainable: caseworker use of the "ideal" mother stereotype against the non-offending mother for failure to protect from child sexual abuse cases' (2013) 69 NYUASAL 311, 326-9.

41 Rebeca J Cook and Simone Cusack, Gender Stereotyping: Transnational Legal Perspectives (University of Pennsylvania Press 2010) 9-13. See also Alexandra Timmer, 'Toward an anti-stereotyping approach for the European Court of Human Rights' (2011) 11.4 HRLR 707, 707-38.

42 Convention on the Elimination of All Forms of Discrimination against Women (Hereinafter CEDAW), Introduction and articles 2(f), 5(a), 10(c); CEDAW Committee, General Recommendation No 25 on article 4, paragraph 1, of the Convention on the Elimination of All Forms of Discrimination against Women on Temporary Special Measures (2004), para 7; CEDAW Committee, General Recommendation No 28 of 16 December 2010 on the core obligations of States parties under article 2 of the Convention on the Elimination of All Forms of Discrimination against Women (2010) CEDAW/C/GC/28, para 9, 22.

43 ibid. 
dishonest and undeserving. ${ }^{44}$ Equality and non-discrimination standards usually also play out significantly in addressing violations stemming from poverty or from perceived 'markers' of poverty. ${ }^{45}$ Alongside violating human rights, such stereotypes justify existing power imbalances.

Different stereotypes do not run on parallel tracks though. Typically, people are confronted with compounded stereotypes. That is, different stereotypes intersect or interact to assign characteristics to members of subgroups of people. ${ }^{46}$ For example, young mothers living in poverty are perceived as incarnating a combination of the aforesaid characteristics. Inadvertently, stereotypes shape social expectations in general, including those of social workers, judges and other actors dealing with child protection services. ${ }^{47}$ As argued below, this played a role in the case of RMS, albeit the ECHR unfortunately - did not say it. In the rewritten judgment I attempt to remedy this silence by (1) examining the merits of the complaint on discrimination; (2) identifying the compounded stereotypes and dominant notions on valued families underlying the decisions of the Spanish authorities; and (3) finding a violation of article 14 ECHR on that account (see paras 97-98 bis).

\section{ASSESSING THE REASONING OF THE COURT FROM AN INTEGRATED APPROACH TO HUMAN RIGHTS}

As already mentioned, human rights law protects the right of children to be cared for and raised by their parents as well as the right of the latter

44 UN Committee on Economic Social and Cultural Rights (CESCR), 'General Comment No 20 of 2 July 2009 on Non-discrimination in economic, social and cultural rights (art 2, para 2, of the International Covenant on Economic, Social and Cultural Rights' (2009) E/C.12/GC/20, para 35; UN, 'Guiding Principles on Extreme Poverty and Human Rights (2012) Principle 21'; UNHRC, 'Report of the UN Special Rapporteur on extreme poverty and human rights, report submitted by Magdalena Sepúlveda Carmona' (2011) A/66/265, para 7.

45 See among others, CESCR, 'General Comment No 20' (n 44), para 35; European Committee of Social Rights, 'Conclusions, General Introduction, January 2014' (2013) 11. See also Sheilagh Turkington, 'A Proposal to Amend the Ontario Human Rights Code: Recognizing Povertyism' (1993) 9 JL\&SP 134, 134; Sandra Fredman, 'Positive Duties and Socio-Economic Disadvantage: Bringing Disadvantage onto the Equality Agenda' (2010) 1 LRPS 1, 6-8; F Pearl Eliadis, Poverty and Exclusion: Normative Approaches to Policy Research (Policy Research Initiative 2004) 18-22.

46 Cook and Cusack (n 41) 29-31. 248-9.

47 Council of Europe, Parliamentary Assembly (n 4), para 9; Cooper (n 34) 
to care for their children. ${ }^{48}$ As a corollary of these rights, article 9 of the CRC sets down very strict conditions for authorizing family separation. The seriousness of the measure and its last resort nature are expressed in two key principles. The first one dictates that children shall not be separated from their parents unless this is necessary for the children's best interest. ${ }^{49}$ The second one is that separation shall be subject to judicial review and all proceedings must be fair. ${ }^{50}$ The Court has drawn similar requirements from article 8 of the Convention. Let's then take these two principles to examine the $R M S$ judgment.

\subsection{Best Interest, Family Separation and Poverty}

Child removal is a highly delicate matter. Only exceptional circumstances that cannot be remedied by other means may justify family separation. ${ }^{51}$ The wording of the CRC refers to 'abuse or neglect of the child by the parents $^{\prime 52}$ and many domestic laws define these and similar notions in detail. Even then, assessing the circumstances under which the legal criteria are met has proven to be challenging. The best interest of the child is the pivotal factor. ${ }^{53}$ However, the CRC Committee has pointed out that the flexibility of the concept of 'best interest' does not only make it more responsive to the actual and diverse situations of children, but also makes it prone to manipulation and abuse by state authorities. ${ }^{54}$ This is the case when poverty or non-conformity with a dominant family model is conflated with neglect or abandonment. ${ }^{55}$ The CRC Committee recalls that, in the same way that the Convention on the Rights of People with Disabilities prohibits children's separation on the sole ground of their or

48 Convention on the Rights of the Child, article 7.

49 Convention on the Rights of the Child (CRC), article 9(1). See also African Charter on the Rights and Welfare of the Child, article 19 and the Preamble and Declaration of the Rights of the Child (1959) article 6.

50 CRC, article 9(1) and (2).

51 Council of Europe, Recommendation of the Committee of Ministers to member states on children's rights and social services friendly to children and families (CM/Rec(2011)12, 2011) 8.

52 CRC, article 9(1).

53 CRC, article 3(1). See also Charter of Fundamental Rights of the European Union, article 24(4).

54 CRC Committee, 'General Comment No 14 of 29 May 2013 on the Right of the Child to have his or her Best Interests taken as a Primary Consideration' (article 3, para 1) (2013) CRC/C/GC/14, para 34.

55 See for example CRC Committee, 'Concluding Observations on Azerbaijan' (2012) CRC/C/AZE/CO/2, paras 37-38; CRC Committee, Concluding observations on Hungary (2006) CRC/C/HUN/CO/2, para 30. 
their parents' disability, ${ }^{56}$ separation for mere economic reasons is not acceptable either. Instead, states should support families and enhance their capacity to care for their children. ${ }^{57}$ Other UN and regional organs have echoed this principle. ${ }^{58}$ Within the Council of Europe, Recommendation Rec(2006)19 of the Committee of Ministers on policy to support positive parenting recommends that member states should create conditions for positive parenting, by ensuring that all those rearing children have access to an appropriate level and diversity of resources. ${ }^{59}$ In providing support, account should be taken of the possible fear of parents in a situation of social exclusion towards social services, particularly of having their children taken away. ${ }^{60}$ In addition to family support, Recommendation Rec (2005)5 of the Committee of Ministers on the rights of children living in residential institutions also reaffirms the principles of last resort and periodical review of child placement as well as the right to maintain regular contact with the child's family and other significant people. ${ }^{61}$

The ECHR has also endorsed the exceptionality of family separation and the pre-eminence of the child's best interest in a number of cases concerning child custody and child removal, including $R M S .^{62}$ Whilst the Court admits that member states enjoy a wide margin of appreciation in evaluating the need for taking a child into care, which can be better assessed by the national authorities who have the benefit of direct contact with the family concerned, it also recognizes that such latitude has to be weighed up against the grave consequences that care orders may entail. Thus, following an initial removal order, stricter scrutiny is necessary for measures further restricting parental rights or limiting access between

56 UN Convention on the Rights of Persons with Disabilities, article 23(4).

57 CRC Committee, 'General Comment No 14' (n 54), paras 61-63.

58 See inter alia, UN, General Assembly, Resolution of 24 February 2010 on Guidelines for the Alternative Care of Children (2010) A/RES/64/142, para 15; Inter-American Commission of Human Rights Doc. 54/13 of 17 October 2013 on The Right of Boys and Girls to a Family. Alternative Care. Ending Institutionalization in the Americas (2013) Report OEA/Ser.L/V/II., 75-78.

59 Council of Europe, 'Recommendation of the Committee of Ministers to member states on policy to support positive parenting' (Rec (2006) 19) Recommendation 3(i).

60 ibid, Recommendation 8(i).

61 Council of Europe, Recommendation of the Committee of Ministers to member states on the rights of children living in residential institutions $(\operatorname{Rec}(2005) 5$, 2005) Appendix to Recommendation, Basic Principles.

62 Kutzner v Germany App no 46544/99 (ECHR, 26 February 2002), paras 75-76; Neulinger and Shuruk v Switzerland App no 41615/07 (GC ECHR, 6 July 2010), para 136; Wallová and Walla v The Czech Republic (n 6), paras 70-72; RMS $v$ Spain (n 1), para 71. 
children and parents. ${ }^{63}$ State authorities must provide sufficiently sound and weighty considerations in the interests of the child. ${ }^{64}$ The intervention must be prescribed by law, oriented towards a legitimate aim, and necessary in a democratic society. The Court has examined the invocation of economic or environmental reasons for child removal and placement under the proportionality requisite. In that context, it has found that 'it is not enough that the child would be better off if placed in care' ${ }^{65}$ Moreover, assessing proportionality has led the Court to evaluate the state's consideration of alternatives and the positive steps undertaken by it to explore them.

Similar to the CRC Committee's approach, the Court determined in RMS that:

the Spanish administrative authorities should have considered other less drastic measures than taking the child into care. The role of the social welfare authorities is precisely to help persons in difficulty ... to advise them on matters such as the different types of benefits available, the possibility of obtaining social housing and other means of overcoming their difficulties, such as those originally sought by the applicant. ${ }^{66}$

So far so good. I applaud the way the Court used the 'less restrictive means test ${ }^{67}$ to highlight the state responsibility in working together with families in the uprising of children. Yet, I regret that the Court seems to adopt a less categorical position than the CRC Committee (and its own previous jurisprudence) when it comes to the illegitimacy of child removal on account of the parents' poverty. This is first noticeable in the way the Court structured its legal analysis which, eventually, omitted to qualify the child separation as disproportional. According to the Court:

the crucial question in the present case is ... whether the national authorities took all the necessary and appropriate measures that could reasonably be expected of them to ensure that the child could lead a normal family life within

63 See for example Johansen v Norway App no 17383/90 (ECHR, 7 August 1996), para 64; Kutzner v Germany (n 62), para 67.

64 Saviny v Ukraine (n 6), para 49.

65 Olsson v Sweden App no 10465/83 (ECHR, 24 March 1988), para 72; Saviny $v$ Ukraine (n 6), para 50; Wallová and Walla v The Czech Republic (n 6), paras $71-72$.

${ }_{66} R M S v \operatorname{Spain}(\mathrm{n} 1)$, para 86.

67 On this 'test' see, Eva Brems and Laurens Lavrysen, "Don't use a sledgehammer to crack a nut": Less restrictive means in the case law of the European Court of Human Rights' (2015) 15 HRLR 139, 139-67. 
her own family, before placing her with a foster family with a view to her adoption. ${ }^{68}$

The reasoning that followed mixed arguments calling into question the removal itself with arguments dealing with the positive steps adopted by the state to avoid the placement of the child in pre-adoption foster care and to achieve family reunification instead. Importantly, the three-fold criterion of legal conformity, legitimate aim and proportionality went overlooked in the judgment. It is unclear why the Court declined to find, as it did in prior similar cases against the Czech Republic and Austria, ${ }^{69}$ that the applicant's financial hardship, even if relevant, was not sufficient to justify the removal of her daughter and, as such, was disproportional.

Second, a sense of ambiguity also flows from the Court's emphasis on the improvement in the economic situation of the applicant. While the Court acknowledges that the applicants' daughter was taken away only because of her mother's difficult economic situation, it recalls that the authorities did not take into account 'subsequent changes in her [economic] circumstances' ${ }^{70}$ The Court further underlines this point by noting that 'the applicant had simply been faced with a shortage of funds' and domestic courts 'refused to take into account the change in the applicant's financial circumstances'. True, the reluctance of domestic courts to assess the financial evidence submitted by the applicant was part of the problem, but not the main one. And, in any case, proving a change in the circumstances originating the child-care order implies that the decision in question was sufficient to justify the separation, which then can be reversed when such sufficient reasons no longer exist. In this case, as in similar cases decided by the Court, the problem is that the sole socio-economic situation of the applicant cannot be considered sufficient justification. So, what if the applicant's economic situation would not have improved? Could this state of affairs have validated the mother-child separation or its prolongation? I do not think so. That is why I would have preferred the Court to focus less on this and more on the illegitimacy of the family separation, on the one hand, and on the positive obligations of the state to protect families against destitution, on the other. With regard to this latter issue, it is of note that while the Court shows commitment in affirming the state duty to support families in difficulties, it is also very cautious in characterizing that endeavour.

\footnotetext{
$68 R M S v \operatorname{Spain}(\mathrm{n} 1)$, para 82.

69 Moser v Austria (n 6); Wallová and Walla v The Czech Republic (n 6); Havelka and Others $v$ the Czech Republic (n 6).

70 ibid, para 85.
} 
The Court uses the verbs 'to help', 'to guide' and 'to advise' with respect to possibilities for obtaining social housing, benefits and other means to overcome the family's difficulties. ${ }^{71}$ I think the Court can say more without compromising the limits of its mandate. After all, rejecting family separation on account of poverty alone necessarily brings about state positive obligations with resource implications, which confirms that no watertight division separates a civil/political right to family life from its socio-economic counterpart. ${ }^{72}$ Because of this, the rewritten judgment first elaborates on the state's duties to ensure that caregivers have access to resources enabling them to perform their childrearing tasks (see para 71 bis). Then, it explicitly forbids the removal of children on the basis of poverty, regardless of any changes in financial circumstances (see para 85).

The CRC Committee and the doctrine are right in firmly proscribing child removal on the basis of poverty alone. This is so not just because such a measure substitutes children's interests with dominant views on valued families while producing disparate or discriminatory effects. Condemning family separation on the sole ground of poverty and demanding state action instead are also necessary to dismantle the ideologies that normalize poverty and the human rights violations suffered by those who struggle with it, and which make of care a 'private' matter. To this I turn in what follows.

\subsection{The Stereotypes at Play: About Gender and Poverty}

In both the administrative and judicial proceedings the situation of the applicant and her daughter was characterized in the following terms: 'The child's mother has two other children who have been abandoned ... No member of the extended family (up to the third degree of kinship) is able to take care of the child'. 'The great-uncle who was put in charge of the other two children ... is overburdened'. 'We are thus dealing with $a$ child whose father cannot be traced, who cannot be taken care of by the person already looking after her two brothers, and whose mother - who appears to have another child under the guardianship of the French authorities - is once again pregnant. ${ }^{73}$ The child needed 'to live in an appropriate family environment'. 'It is clear ... that, whether as a result of ignorance, other impediments, lack of social skills or any other reason, including possible

71 ibid, para 86.

72 Airey v Ireland App no 6289/73 (ECHR, 9 October 1979), para 26.

$73 \quad R M S$ v Spain (n 1), para 34. 
mental illness ... the child was in a state of wholesale physical and psychological neglect. ${ }^{74}$ 'Notwithstanding the applicant's assertion that she spoke three languages, she had not attempted to make use of those skills, living in a situation of social and professional isolation which forced her to emigrate or move around in order to find work.' As to the applicants' capacity to have her children living with her, domestic judges noted that testimonies '[had] not provide[d] any evidence of [the applicant's] social and professional stability and of an absence of risk for the child, still less [had] they demonstrated how the child would benefit from being returned to her original family. ${ }^{75}$ The applicant's behaviour after the child removal was described as 'disruptive of the child's emotional stability'. She was 'disrespectful and violent' because she 'had not accepted the visiting hours [and] had screamed when the end of the visits approached'.

In light of the above, the applicant's claim that she was discriminated against and that the authorities had been biased in favour of separating her from her daughter should be taken seriously ${ }^{76}$ Similarly to CEDAW's condemnation of gender stereotypes, the UN Guiding Principles on Extreme Poverty and Human Rights underscore the need to protect persons living in poverty from discriminatory stigmas attached to conditions of poverty. ${ }^{77}$ Moreover, the EU Parliamentary Assembly acknowledges the link between discrimination, the over-representation of vulnerable groups in the care population and the incidence of stereotypes and prejudice. ${ }^{78}$

Compounded stereotypes and prejudices appear to be at play in the decisions taken by the Spanish authorities. The applicant was depicted as a disinterested mother, whose other children were considered abandoned and at risk because she placed them under the guardianship of her great-uncle. Her extended family constituted an inappropriate environment and no one there, including the applicant herself, was seen as apt for childrearing. She is sexually irresponsible (the father of her child is unknown and she is once again pregnant). She is also blamed for her own destitution, bearing the stigma of not making sufficient efforts despite her skills. She is a bad mother who instead of staying close to her children emigrated or moved around to work. And when she dares to complain, she is violent, maniac

\footnotetext{
74 ibid, para 30.

75 ibid, para 43.

76 Council of Europe, Parliamentary Assembly (n 4), paras 6, 8, 9, 54-55.

77 UN Guiding Principles (n 44), Principle 21.

78 Council of Europe, Parliamentary Assembly (n 4), para 54. See also Council of Europe $(\operatorname{Rec}(2005) 5,2005)$ (n 61), basic principle on the prohibition of discrimination in decisions concerning child placement.
} 
or mentally ill. These popular images about impoverished single mothers are not infrequent and have been documented elsewhere. ${ }^{79}$

The ECHR singled out that the Spanish authorities merely reiterated the assertions made by the social workers and that no expert report supported them. Moreover, the Court also observed that the applicant was forced to prove that she was a good mother, while no evidence submitted to that effect could overcome the judicial authorities' assumptions. However, the Court did not acknowledge that in doing so the state authorities relied on negative stereotypes concerning the applicant's gendered roles and her socio-economic status. The importance of identifying and combating gender stereotypes is well-grounded to date. ${ }^{80}$ And although more needs to be done in this respect, improvements are visible within the ECHR and other supranational organs. ${ }^{81}$ The situation looks less promising, however, when it comes to social stigma attached to class status or poverty. Perhaps because the application of non-discrimination norms for reasons of poverty is resisted or because discourses of difference may tend to side-line socio-economic disparities, misrecognition associated with the experience of poverty is yet to be challenged by courts like the ECHR and other monitoring organs. ${ }^{82}$ Doing so in a case like $R M S$ is necessary not only to overcome status subordination - and ensure recognition - but also to destabilize the social structures that personalize - 'privatize' - both individual and family material well-being and the 'failings' in accomplishing it. That is, striving for better distribution. In fact, 'struggles for recognition can aid the redistribution of power and wealth'. ${ }^{83}$

The fact that the Court did not engage in this analysis and concluded instead that there was no separate issue to address under article 14 of the Convention may be partly explained by the fact that the applicant did not

79 J. Bruce Porter, Affidavit before the Superior Court of Justice, Ontario, Between Dale Broomer et al and Attorney General of Ontario et al. (2002) Court File No: 02-CV-229203 CM3, paras 28-37; Winograd (n 40) 328-9; Shruti Rana, 'Restricting the rights of poor mothers: An international human rights critique of "workfare" (2000) 33 CJL\&SP 393, 404-11.

80 See references above in nn 39 and 40.

81 On the ECHR see Timmer (n 41) 717. See also Atala Riffo and daughters $v$ Chile (IACtHR, 24 February 2012), paras 109, 111; Artavia Murillo et al. ("In vitro fertilization") v Costa Rica (IACtHR, 28 November 2012), paras 294-7.

82 Similar concerns have been raised with regard to domestic courts. See for example Colleen Sheppard, "Bread and roses": Economic justice and constitutional rights' (2015) 5 OSLS 225, 235-7; Michele Benedetto, 'Socio-economic bias in the judiciary' (2013) 61 CSLR 137, $146 \mathrm{ff}$.

83 Nancy Fraser, 'Rethinking Recognition' (2000) 3 NLR 107, 109. 
further elaborate her complaint of discrimination. ${ }^{84}$ Actually, from the parties' arguments reproduced in the judgment, questions of stereotyping do not appear to have been brought forward. Yet, there are three main considerations that led me to propose, when redrafting $R M S$, that the Court should have analysed the merits of the claim of discrimination on the basis of the harmful stereotypes described above and should even have found a violation of article 14. The first one is that leaving aside the applicants' framing and argumentation, the Court seems to have the tendency to avoid complex questions of discrimination by declining to examine the merits of discrimination complaints and referring to its own findings under other provisions. ${ }^{85} \mathrm{I}$ advocate for abandoning this practice. Second, cases like $R M S$ provide the opportunity to challenge the social stigma and negative stereotypes attached to poverty through the prohibition of discrimination. Third, when viewed from the perspective of children, it is rather uncontested that children cannot be discriminated against in the enjoyment of their right to parental care on the basis of their or their family's socio-economic origin or circumstances. Hence, while admittedly the Court was confronted with a scant substantiation of the allegation of discrimination, I deliberately use this rewriting exercise to stretch the Court's faculties of adjudication in order to move forward in naming and condemning the compounded discriminatory assumptions that justify the separation of mother and children living in poverty (see paras 97-98 bis of the rewritten judgment).

\subsection{The Decision-making Process: Judicial Review, Fairness and Participation}

The applicant in $R M S$ complained that domestic courts had not revised the 'irregularities' in the child-care measures adopted by the administrative authorities. According to the Court's case law, article 8 of the Convention requires certain procedural guarantees to be met in order to ensure that the decision-making process over care orders affords adequate protection to the parents' and children's interests. ${ }^{86}$ The ECHR, however, dismissed most of the applicant's claim. It considered that, since a lawyer had

\footnotetext{
$84 R M S v$ Spain (n 1), paras 95, 98.

85 In this vein, Colm O'Cinneide, 'The right to equality: A substantive legal norm or vacuous rhetoric?' (2008) 1 UCLHRLR 80, 83-4 91-4.

86 Sahin v Germany App no 30943/96 (ECHR, 8 July 2003), para 63; Barbara Kussbach, 'Effective human rights protection for children in care. Does the UK provide effective remedies under the European Convention on Human Rights against the non-implementation of care orders?' (2007) 4 EHRR 1, 12.
} 
represented the applicant before the judicial authorities and she had been able to present submissions to support her case, there were no discernible failings attributable to the domestic courts in this respect. The Court only questioned the conduct of the judicial authorities to the extent that they limited themselves to reiterate the assertions made by the social services and allowed the lapse of time to uphold the girl's placement in pre-adoption foster care, frustrating family reunification. ${ }^{87}$ However, in my view, the applicant's complaint can hardly be limited to that. It is plausible to think that her discontent was also linked to the lack of a timely and thorough judicial review in the first place. The applicant was able to judicially challenge the decisions taken since 1 February 2006 (about six months after the removal) and a judicial hearing took place more than a year and a half after the separation, without the participation of all interested parties. These shortcomings seem to have gone rather unnoticed in $R M S$. I contend that the Court could have further engaged with the actual experience of the applicant and her daughter along the judiciary and with the array of judicial guarantees afforded by the international corpus of children's rights.

UNICEF and the CRC Committee have both underscored that state reservations to article 9 CRC (judicial control over child separation) based on domestic legislation authorizing social workers to take children into care without a court hearing or judicial review are incompatible with the rights of the child.$^{88}$ In the applicant's case there was judicial review, but it came too late. The wording of article 9 CRC does not contain an express requirement of speediness. Nonetheless, the provision cannot be interpreted as lacking such a requisite. This, like the judicial intervention in itself, is needed in order to ensure an effective judicial oversight over administrative child removal and placement. At the time of drafting article 9, many state representatives emphasized the need to expedite judicial review so as to ensure that the separation period would be the shortest possible ${ }^{89}$ Furthermore, articles 8 and 12 CRC are also relevant in interpreting article 9. The former demands that a child's identity, including family ties, be 'speedily' re-established. Under article 12 every

$87 \quad R M S v$ Spain (n 1), para 92.

88 UNICEF, Implementation Handbook for the Convention on the Rights of the Child (3rd edn, 2007) 129. See also Committee on the Rights of the Child, Concluding Observations to Lebanon (2002) CRC/C/15/Add.169, paras 36-7.

89 Travaux Préparatoires, UN Doc E/1982/12/Add.1, C, 49-55 reproduced in Sharon Detrick (ed.), The United Nations Convention on the Rights of the Child. A Guide to the Travaux Préparatoires (Martinus Nijhoff 1992) 168; UNICEF (n 88), 128. 
child is entitled to be heard and have his or her views considered in any administrative or judicial procedure affecting the child.

In 2012 the South African Constitutional Court declared part of the Children Protection Act to be unconstitutional insofar as it failed to provide for automatic judicial review of child removal and placement decisions made by social workers or police officials. Interestingly, the case leading to the judgment concerned the removal of children from parents living in poverty.$^{90}$ Invoking the $\mathrm{CRC}$, the Constitutional Court reasoned as follows:

It might be argued that this remedy is already available, since no provision precludes the family from approaching a court ... Although this may be true in a formal sense, it is not true in a functional sense. It is unfair for the law to empower the state to initiate the removal of a child from her or his family, but to place the onus on the affected family to initiate the review of that removal. By requiring the family to bear, at least initially, the cost of pursuing review proceedings, the impugned provisions are too restrictive of [the] children's rights protected. ${ }^{91}$

A contextualized approach like this one is missing in the $R M S$ judgment. Moreover, and besides the issue of promptness, an effective judicial review of child removal requires that all interested parties, including the child, be heard in the proceedings, which must be conducted before specialized courts. ${ }^{92}$ In $R M S$, however, the applicants' extended family was not allowed to participate in the judicial proceedings. While the Court observed that the applicant's great-uncle had not had an opportunity to express his views in the judicial proceedings (and therefore the finding that he was 'overwhelmed' to care for the child lacked supportive evidence), it did not explicitly frame this as a flaw in the decision-making process. Additionally, the non-specialized character of the domestic courts did not motivate any comment from the Court.

Neither was the applicant's child involved in the proceedings. As to whether and how the judicial and administrative authorities endeavoured to hear the child and have her views taken into consideration, some preliminary remarks are needed. First, the right of the child to be directly heard in court is not absolute and due regard to his or her age and maturity may justify a limitation to that right. ${ }^{93}$ Second, national courts

90 C and Others v Department of Health and Social Development, Gauteng and Others Case CCT 55/11 (Constitutional Court of South Africa, 11 January 2012).

91 ibid 37.

92 Convention on the Rights of the Child, article 9(2).

93 Convention on the Rights of the Child, article 12; Committee on the Rights of the Child, General Comment of 1 July 2009 on Article 12: The Right of the Child to be heard (2009) CRC/C/GC/12, paras 20-21; Guidelines of the 
enjoy discretion as to the means to ascertain the relevant facts of a case, including those affecting children. ${ }^{94}$ In $R M S$ the applicant's daughter was aged three years and ten months when she was taken into care, about five years and six months at the time of the first judicial hearing and eight years when the foster care decision was upheld. In Sahin v Germany, ${ }^{95}$ the Court observed that the child was about three years and ten months old when the appeal proceedings on her custody started, and five years and two months at the time of the Regional Court's decision. The Court was of the opinion that despite the fact that the girl was not heard by the German courts, they did not overstep their margin of appreciation. The Court reached that conclusion after being satisfied that a well-trained expert had interviewed the girl and her parents, evaluated her attitude towards them and concluded that hearing the child in court may had entailed a risk for her. ${ }^{96}$ In $R M S$, however, we do not find any similar evaluation of the steps undertaken by the Spanish authorities to address the issue of child participation and the consideration of her views before the domestic courts and the administrative authorities. ${ }^{97}$ In the rewritten judgment, these omissions are remedied in the analysis of the fairness of the decision-making processes (see paras 78-81 ter).

\section{CONCLUSION}

The case of $R M S v$ Spain is reflective of the fact that poor families, particularly poor women and children, are too often disproportionally impacted by child protection schemes which rely on a 'privatized' and gendered notion of child care. In short, poverty is frequently mistaken for child neglect. And parents, or more precisely, mothers, are seen as the main or the sole person responsible for that. This image is fuelled by prejudices about the experience of poverty and dominant notions on valued families. A common result is child separation from young, single mothers who, as the primary care-givers and the main target of the aforesaid preconceptions, are overly deprived of their parenting rights, with the ensuing harm for their children. This chapter has attempted to demonstrate that although

Committee of Ministers of the Council of Europe on Child-friendly Justice and their Explanatory Memorandum, (adopted on 17 November 2010, edited 31 May 2011) Explanatory Memorandum. General Comments, (Participation), para 32.

94 Sahin v Germany (n 86), para 73.

95 ibid.

96 ibid, paras 74-77.

97 In conformity with Council of Europe (CM/Rec(2011)12, 2011) (n 51) 7. 
the judgment on $R M S$ is overall welcome, its reasoning could have been improved by undertaking an integrated approach to the rights of women and children living in poverty. Such approach calls upon the Court (1) to unequivocally declare the disproportionality of the care orders and the impermissibility of family separation on the sole grounds of poverty; (2) to challenge the harmful stereotypes at play and acknowledge their discriminatory effect; and (3) to further scrutinize the decision-making processes. This integrated framework would not only have better done justice to the existing rights regimes applicable to women and children living in poverty, but also to the lived experience of the rights holders involved in the case. 


\title{
APPENDIX
}

\author{
THE LAW
}

I. ALLEGED VIOLATION OF ARTICLE 8 OF THE CONVENTION

\section{The Court's assessment}

\section{(a) General principles [fragment deleted]}

69. [Original paragraph 69 deleted] According to the Court's established case law, the mutual enjoyment by parent and child of each other's company constitutes a fundamental element of family life (see Kutzner v. Germany, § 58; Saleck Bardi v. Spain, no. 66167/09, § 50, 24 May 2011, § 49). Domestic measures hindering family ties, such as care proceedings, constitute an interference with the right protected by Article 8 of the Convention ( $K$. and T. v. Finland [GC], no 25702/94, § 51). The interference will be justified if it is prescribed by law, pursues one or more legitimate aims under the second paragraph of this provision and is necessary in a democratic society to achieve them (Wallová and Walla v. The Czech Republic, no. 23848/04, $\S 68)$. In assessing whether the measure was "necessary in a democratic society", two aspects of the proceedings or measures require consideration. Firstly, the Court must examine whether, in the light of the case as a whole, the reasons adduced to justify the measures were "relevant and sufficient"; secondly it must examine whether the decision-making process was fair and afforded due respect to the applicant's rights under Article 8 of the Convention (see $K$. and $T$. v. Finland, cited above, $\S 154 ; R$. and $H$. v. the United Kingdom, no. 35348/06, $§ \S 75$ and 81, 31 May 2011).

70. [Original paragraph 70 deleted] The Court reaffirms the principle established in its case-law under article 8 and contained in Article 9 of the Convention on the Rights of the Child according to which States Parties shall ensure that a child shall not be separated from his or her parents against her will, except when competent authorities subject to prompt and periodical judicial review determine, in accordance with applicable law and procedures, that such a separation is necessary in the best interests of the child. Such determination may be necessary in very serious cases such as those involving abuse, injury or neglect of the child. In this context, the Court recalls that it is not enough to show that a child could be placed in a more 
beneficial environment for his or her upbringing (see Wallová and Walla $v$. The Czech Republic, cited above, $\$ 71)$. Family separation must be supported by sufficiently sound and weighty considerations in the interests of the child. Furthermore, where such a decision has been taken, all interested parties shall be given an opportunity to participate in the respective administrative and judicial proceedings and make their views known.

71. [Fragment deleted] In addition, the Court has repeatedly held that ... taking a child into care should normally be regarded as a temporary measure to be discontinued as soon as circumstances permit, and any measures implementing temporary care should be consistent with the ultimate aim of reuniting the natural parents and the child (see $K$. and T. v. Finland [GC], no. 25702/94, § 178, ECHR 2001-VII). The positive duty to take measures to facilitate family reunification as soon as reasonably feasible will begin to weigh on the competent authorities with progressively increasing force as from the commencement of the period of care, subject always to its being balanced against the duty to consider the best interests of the child. Furthermore, the positive obligations are not confined to ensuring that children can rejoin their parents or have contact with them, but also extend to all the preparatory steps to be taken to that end (see, mutatis mutandis, Kosmopoulou v. Greece, no. 60457/00, § 45, 5 February 2004, and Amanalachioai v. Romania, no. 4023/04, § 95, 26 May 2009). [Fragment deleted]

71 bis. Positive measures under Article 8 also require States to support families and caregivers in childrearing, especially where they are in a situation of vulnerability. In this connection, Recommendation $\operatorname{Rec}(2006) 19$ of the Committee of Ministers of the Council of Europe on policy to support positive parenting, adopted on 13 December 2006, indicates that policies and measures in the field of support for parenting should take into account the importance of a sufficient standard of living to engage in positive parenting. Governments should also ensure that children and parents have access to an appropriate level and diversity of resources (material, psychological, social and cultural). The Court notes that in its 2010 concluding observations on Spain, the Committee on the Rights of the Child expressed its concern about the fact that many families still lack appropriate assistance in the performance of their child-rearing responsibilities, in particular families in crisis situations due to poverty, absence of adequate housing, or separation. The Committee was particularly concerned at the situation of children in families of foreign origin and single-parent families. (CRC/C/ESP/3-4, adopted at its 1583rd meeting, held on 1 October 2010) 
72. Each Contracting State must equip itself with an adequate and sufficient legal arsenal to ensure compliance with the positive and negative obligations imposed on it under Article 8 of the Convention. The Court acknowledges that the adoption of childcare measures is a very sensitive matter that poses difficult questions to State authorities. Moreover, domestic authorities have the benefit of direct contact with all the persons concerned and therefore are better placed to assess the circumstances of each case. While it is not the Court's task to substitute itself for the domestic authorities, [fragment deleted] it is for the Court to ascertain whether the domestic authorities, in applying and interpreting the applicable legal provisions, secured the guarantees set forth in Article 8 of the Convention, particularly taking into account the child's best interests (see, mutatis mutandis, Neulinger and Shuruk v. Switzerland [GC], no. 41615/07, § 141, ECHR 2010, and K.A.B. v. Spain, cited above, § 115).

(b) Application of these principles in the present case

77. [Original paragraph 77 deleted] The Court observes that it is not contested that the decision to place the applicant's child in institutional and foster care as well as to restrict the applicant's contact rights constituted an interference with her right to respect for her family life within the meaning of Article $8 \S 1$ of the Convention. It must therefore be determined whether the interference was justified under Article $8 \S 2$, namely, whether it was in accordance with the law, pursued a legitimate aim and was necessary in a democratic society. Based on Articles 172 and 173 of the Spanish Civil Code and further domestic law provisions (see paragraph 53 above), the Court finds that the contested measure was "prescribed by law". It also appears from the motivation provided by the administrative and judicial authorities that their decisions were aimed at safeguarding the best interests of the applicant's child. The interference in question therefore pursued the legitimate aim of protecting the rights and freedoms of others under Article $8 \S 2$. Accordingly, the Court shall focus on determining whether such interference satisfied the requirements of necessity in a democratic society. This implies an examination of the proportionality of the contested measures, which must be based on relevant and sufficient reasons, and on the fairness of the decision-making process. The court shall first examine this last requirement.

\section{Fairness of the decision making-processes: speediness and participation}

71. [Original paragraph 78 deleted, save one fragment] The Court observes that the administrative authorities were empowered to take the 
applicant's daughter into care, declare her abandonment and undertake her guardianship. While the applicant was entitled to challenge these decisions before a court, in the meantime the administrative authorities decided to provisionally place her daughter in foster care. In this context, the Court is of the view that prompt access to a court by the family and the child concerned as well as regular judicial review of the measures adopted were of the utmost importance. The Court observes that in the present case ... the applicant was able to present submissions in support of her case, in the context of judicial proceedings in which she was represented by a lawyer, at least from 1 February 2006 onwards. However, the Court views with concern that about six months elapsed between the child's removal and the applicant's intervention in those proceedings. Furthermore, a hearing before the nonspecialised Granada first instance judge no. 3 concerning the declaration of abandonment only took place in May 2007 (about a year and a half after the removal).

72. The Court observes that, in cases concerning family life, the breaking-off of contact with a very young child may result in the progressive deterioration of the child's relationship with his or her parent (see, among other authorities, Pini and Others $v$. Romania, nos. 78028/01 and 78030/01, $\S 175$, ECHR 2004-V (extracts), and K.A.B. v. Spain, cited above, $\S 103$ ). This also holds true in the present case. In this regard, the Court observes that expedited judicial review is crucial to ensure that the separation period be as short as possible. A requirement of speediness is therefore implicit in the procedural safeguards imposed by Article 8. Domestic authorities are also expected to regularly examine the family situation. This interpretation is furthermore consistent with Articles 8, 9 and 12 of the Convention on the Rights of the Child.

3. In assessing the quality of the decision-making process leading to the splitting up of the family, the Court takes into account, in particular, whether the conclusions of the domestic authorities were based on adequate evidence (including, as appropriate, statements by witnesses, reports by competent authorities, psychological and other expert assessments and medical notes) and whether the interested parties, in particular the parents or caregivers, including members of the extended family as well as the child concerned when applicable, had sufficient opportunity to participate in the procedure in question (see Saviny v. Ukraine, no. 39948/06, § 51, 18 December 2008). In view of these considerations . . . the Court notes a serious lack of diligence in the procedure implemented by the authorities responsible for the child's guardianship, placement and possible adoption (see $\$ \S 88-90$ below) (see K.A.B. v. Spain, cited above, $\S 104)$. 
81 bis. [Original Paragraph 88 modified] [Fragment deleted] The Court notes that the judge rejected [the applicant's] proposal of placing her daughter in the foster care of her great-uncle on the grounds that the applicant's great-uncle was not a suitable candidate for fostering minors, without giving any reasons for this assertion, but simply stating that the applicant's great-uncle would be "overburdened" since he was already taking care of the applicant's other two children (see paragraph 34 above). The Court is in agreement with the UN Committee on the Rights of the Child that protection of the family extends to the maintenance of ties with members of the extended family (General comment No. 14 on the Right of the Child, CRC/C/GC/14, 2013, §§ 59-60). Thus, the Court regrets that domestic authorities had disregarded, without motivation, such alternative for keeping "G" under the care of the great-uncle. This would have allowed the girl to remain close to her family, including her siblings who were also under the care of the applicant's great-uncle. This alternative had to be assessed within the context of the applicant's extended family, her particular living circumstances and the views of all the parties concerned. As the applicant's greatuncle was not granted leave to take part in the proceedings, he did not have an opportunity to express his views on the subject. This runs against the requirements of fairness and participation of all parties concerned embodied in the procedural aspects of Article 8, which is line with Article 12 of the Convention on the Rights of the Child.

81 ter. The Court considers that, had the applicant's vulnerability at the time her daughter was taken into care been taken into consideration, this might have played an important role in understanding the situation of the child and her mother within both the administrative and the judicial proceedings. [Fragment deleted]. In addition to the applicant's great-uncle's participation in the judicial proceedings, the Court is of the view that the issue of the child's participation must also be considered. The Court observes that as a general rule it is for the national courts to assess the evidence before them, including the means used to ascertain the relevant facts (Sahin v. Germany, no. 30943/96 § 73). Moreover, the question of hearing a child also depends on the specific circumstances of each case, having due regard to the age and maturity of the child concerned. The Court notes that the applicant's daughter was aged three years and ten months when she was taken into care, about five years and six months at the time of the first-instance judge hearing and eight years when the foster care decision was upheld. However, the material before the Court's consideration does not provide any indication as to whether and how the administrative and judicial authorities ascertained at any time the possibility to hear G's views and assess her wishes. Taking into account the foregoing, the Court is of the opinion that the decision-making 
process was not based on sufficient evidence nor allowed the participation of all the persons involved, including the child concerned.

4. [Paragraph 82 deleted]

2. Relevant and sufficient reasons to justify family breakdown: prohibition of separation on the sole ground of poverty and State duties to support childrearing

5. Even assuming that in the circumstances of the case the social worker A.L.N. may had had reason to believe that [fragment deleted] the situation and the best interests of the child [fragment deleted] made necessary to place the applicant's child in a home, the decision in question should have been followed swiftly by appropriate measures to examine in depth the child's situation and her relationship with her parents or caregivers, while complying with the rules in force . . The Court notes that no consideration was given at any stage of the administrative procedure to the fact that the child had been very young when she was separated from her mother, to the existing emotional bond between mother and child and between the latter and her siblings and extended family or to the length of time that had elapsed since their separation and the attendant consequences for both of them.

6. In contrast to other cases which the Court has been called upon to examine, the applicant's child in the present case had not been subjected to violence or to physical or psychological ill-treatment [references deleted]. The courts did not note any lack of emotional development (see, conversely, Kutzner v. Germany, no. 46544/99, § 68, ECHR 2002-I), or any worrying health problems on the part of the child or psychological instability on the part of the parents [references deleted]. While it is true that in some cases declared inadmissible by the Court, the children concerned may have been placed in care because of unsatisfactory living conditions or material deprivation, this was never the sole reason on which the decision of the domestic courts was based, since other factors such as the psychological state of the parents or their inability to provide their child with emotional and educational support were also considered [references deleted].

7. In the present case the applicant's ability to provide her minor daughter, G., with educational and emotional support was not formally at issue [fragment deleted]. The care order in respect of the applicant's child was made because of the applicant's difficult financial situation at the time. 
The Court considers that financial constraints or poverty should never be the only justification for the removal of a child from his or her family nor can this circumstance legitimise the prolongation of the family separation. Financial difficulties should rather prompt authorities to provide adequate support to the family in question. This principle is enshrined in the UN Guidelines for the Alternative Care of Children and has been upheld by the UN Committee on the Rights of the Child and the Parliamentary Assembly of the Council of Europe (Doc. 13730, 13 March 2015, §§ 14, 48-53). Thus, the shortage of funds faced by the applicant was [fragment deleted] a situation which the national authorities could have helped remedy by means other than the complete break-up of the family, a measure of last resort to be applied only in the most serious cases.

8. In the Court's view, the Spanish administrative authorities should have considered other less drastic measures than taking the child into care. Before considering the split of the family, public authorities have a key role to play in supporting families and their childrearing functions. The role of the social welfare authorities is precisely to help persons in difficulty who are not sufficiently familiar with the system, to provide them with guidance and to advise them on matters such as the different types of benefits available, the possibility of obtaining social housing and other means of overcoming their difficulties, such as those originally sought by the applicant (see paragraph 8 above). Moreover, States are particularly called upon to fulfil their supportive duties with regard to families in a situation of greater vulnerability such as that of the applicant who was a single young mother experiencing socio-economic difficulties. The Court also regrets that instead of examining whether steps could be taken to assist the applicant and avoid family separation, the judgment of 18 May 2007 limited itself to conclude, without any supportive evidence, that the child was in a state of wholesale physical and psychological neglect either as a result of the ignorance, lack of social skills or possible mental illness of the applicant.

9. The Court further notes that the initial finding that G. had been abandoned was reproduced automatically throughout the subsequent procedure, during which the intention of the administrative authorities to place the child elsewhere was clearly expressed ... In the Court's view, the administrative and judicial authorities simply relied on stereotyped views of the applicant (see paragraphs 97-98 bis below) and reproduced the successive decisions without making any new findings or assessing how the circumstances might have changed on the basis of tangible evidence. 
10. [Original paragraph moved to and transformed in new paragraph 81 bis above]

11. [Original paragraph moved to and transformed in new paragraph 81 ter above]

93. In view of these considerations and notwithstanding the margin of appreciation enjoyed by the respondent State in the matter, the Court concludes that the Spanish authorities [fragment deleted] did not provide sufficient reasons to justify the issuance of the care orders and failed to adopt appropriate positive measures to assist the applicant in overcoming her material difficulties and secure the right to family life of the applicant and her daughter. The State party also failed to ensure the fairness of the decision making-process leading to the enforcement of the care orders in breach of Article 8. All this renders the family separation disproportional.

12. Accordingly, there has been a violation of Article 8 .

\section{ALLEGED VIOLATION OF ARTICLE 14 IN CONJUNCTION WITH ARTICLE 8 OF THE CONVENTION}

95. The applicant complained of discrimination on the grounds of her race, her Guinean origin, the colour of her skin, her physical appearance, her culture and way of life, since the extended structure of her family was not understood by the Spanish courts. She relied on Article 14 of the Convention.

96. The Government contested that argument.

97. [Original paragraph deleted] According to the Court's case law, Article 14 comes into play whenever the measures complained of are linked to the exercise of a right guaranteed by the Convention. The Court notes that this complaint is linked [fragment deleted] to the circumstances that led to the forced separation of the applicant and her child in violation of Article 8. The applicant alleges that the authorities were biased against her (see paragraph 64 above) and claims that she has been discriminated against on the basis of, inter alia, her race, physical appearance and way of life. According to Recommendation $\operatorname{Rec}(2005) 5$ of the Committee of Ministers, the decision taken about the placement of a child and the placement itself should not be subject to discrimination, including on the basis of social origin or any other 
status of the child and/or his or her parents. Furthermore, the Court is of the view that the disproportionate taking of children into care from particularly vulnerable groups such as households led by single women, parents and children with disability or families living in poverty, may be indicative of discrimination. This also holds true where care orders are made on the basis of discriminatory attitudes and assumptions such as harmful stereotypes that regard certain persons as incapable of parenting. In light of the foregoing, and given that the Court is the master of the characterization to be given in law to the facts submitted to its examination, the Court is of the opinion that the applicant's complaint under Article 14 in conjunction with Article 8 may be characterized as a complaint of intersectional discrimination on the grounds of gender, race and social origin or "other social status". Thus, the applicant's complaint under Article 14 in combination with article 8 is admissible.

97 bis. While the Court observes that no statistics or data concerning the over-representation of impoverished single mothers or afro-descendant population in child welfare proceedings has been submitted before it, it is of the view that the applicant's allegations must be viewed in light of the reasons provided by the administrative and judicial authorities involved in the implementation of the care orders in respect of $G$. and in the restriction of the applicant's contact rights. In this connection, the Court reiterates its concern regarding the unfounded assertions made by State authorities as to the supposed abandonment of $G$. and her siblings as well as the alleged inability of the applicant and her great-uncle to care for G. Further, the Court is struck by the assumptions invoked by the judicial authorities as to the supposed ignorance, lack of social skills, mental illness and neglectful behaviour of the applicant (see paragraphs 30, 34 and 43 above). The Court also takes notes of the domestic authorities' assumptions concerning insufficient efforts made by the applicant to overcome her socio-economic difficulties and the requirement of evidence to prove that the applicant's child would benefit from being reunited with her mother.

98. [Original paragraph deleted] The Court notes with concern that the aforesaid authorities' assertions, lacking any concrete evidence, denote negative stereotypes about the applicant on the basis of her role as a mother and her socio-economic status. The State has not provided evidence to contest the stereotyped nature of those views, which constituted the only basis to separate the applicant from her daughter. The Court recalls the position of the UN Committee on the Elimination of Discrimination against Women according to which harmful gender stereotypes constitute a form of discrimination against women (General recommendation No. 
28, CEDAW/C/GC/28, 16 December 2010, § 22). The Court also takes note of the UN Guiding Principles on Extreme Poverty and Human Rights (adopted by the Human Rights Council on 27 September 2012, in resolution 21/11, Principles 21 and 72) and the views expressed by the UN Committee on Social, Economic and Cultural Rights (General Comment No. 20 on Non-discrimination in economic, social and cultural rights, E/C.12/GC/20, 2 July 2009, § 35) as well as the Special Rapporteur on the Rights of People Living in Poverty (report submitted by Magdalena Sepúlveda, A/66/265, $2011,2011, \S 7$ ) with regard to prejudice and stigma for reasons of poverty and the prohibition of discrimination on the grounds of social condition or socio-economic status. Harmful stereotypes related to poverty include the assumption that persons in socio-economic disadvantage are responsible for their own destitution, do not make enough efforts to overcome it and neglect their children. In the case at hand, the Court is of the view that prejudiced views related to poverty intersected with gender stereotypes, giving rise to misconceptions about the lack of parenting capacities of the applicant in her condition as an impoverished single woman living within an unconventional family. Furthermore, the Court is in agreement with the Inter-American Court of Human Rights' finding that "a determination based on unfounded and stereotyped assumptions about the parent's capacity and suitability to ensure and promote the child's wellbeing and development is not appropriate for the purpose of guaranteeing the legitimate goal of protecting the child's best interest." (Case of Atala Riffo and daughters v. Chile, Judgment of 24 February 2012, § 111)

98 bis. The Court concludes that the authorities' reliance on such stereotypes, even if unintended, constitutes discrimination prohibited by Article 14. In addition, the prohibition of discrimination set out in Article 2 of the Convention of the Rights of the Child in combination with Article 9 of the same instrument requires States Parties to ensure that children are not discriminated against in their enjoyment of parental care on the basis of their family configuration, including its socio-economic circumstances and structure. In sum, there has been a breach of Article 14 in conjunction with Article 8. 